(d) may provide for the making of forestry surveys and provide advice relating to the protection and management of forests on lands administered by any department or agency of the Government of Canada or belonging to Her Majesty in right of Canada; and

(e) at the request of any department or agency of the Government of Canada, may assume responsibility for the protection and management, including the disposal of timber and other forest products, of any forest on lands administered by such department or agency.

These duties and powers obviously offer wide scope for activity and fears have been voiced that the federal government will be infringing upon provincial prerogatives. However, the Prime Minister and several other Cabinet members have repeatedly emphasized that care will be taken to avoid any such encroachments. Nevertheless there is little doubt but that the new department will greatly increase the federal government's efforts to provide information necessary for good forest management and marketing of wood products.

\title{
Toronto Diploma Course in Resource Management
}

The Senate of the University of Toronto has recently approved the establishment of a one-year post-baccalaureate course in resource management leading to a diploma (D.R.M.), to begin in September, 1961, with provision for a limited number of candidates for the forthcoming session.

The course, which is open to graduates in either forestry or biology, is intended to bring together the various parts of zoological and forestry information that relate directly to the management of the renewable natural resources. It is not intended as an introduction to qualification for research, but rather to broaden the technical knowledge and understanding of those engaged in resource management and administration; hence it is a terminal course and provides no credit towards a postgraduate degree program. The course is sponsored jointly by the Department of Zoology and the Faculty of Forestry, and is to be administered by a committee of the Council of the Faculty of Forestry.

Enquiries for further information should be addressed to the Secretary, Faculty of Forestry.

\section{G. L. LOWRY JoINS P.P.R.I.C.}

Dr. Gerald L. Lowry joined the staff of the Pulp and Paper Research Institute of Canada on July 1 as Forester (Forest Soils) in the Woodlands Research Department.

The addition of Dr. Lowry to the present Woodlands Research team, which already includes a tree physiologist and forest ecologist among its foresters and engineers, will enable the Institute to fill out and expand that part of its woodlands program concerned with the regeneration and growth of forest stands for more efficient pulpwood production.

\section{INDUSTRIAL Forestry Seminar}

The College of Forestry of the University of Washington will cooperate with the Yale University School of Forestry in presenting the Seventeenth 